\title{
Express-assessment of potential hazard of water by method of biotesting using Daphnia magna S.
}

\author{
E. Arystarkhova, \\ Candidate of Biological Sciences, \\ Institute of Agroecology and Environmental Management of National Academie of Agrarian \\ Sciences
}

The purpose. Increase of selfdescriptiveness of biotesting waters of surface sources of water service and drinking water on shellfishes Daphnia magna S. due to use of the test-attribute of frequency of cordial beatings (FCB). Methods. Biotesting by determination of immobilization of $D$. magna during 48-hour exposure and FCB - in conditions of 3-hour exposure. Results. Toxicity of water is not fixed at absence of immobilization of $D$. magna. By index of FCB their low level of toxicity $(26,2-35,4 \%)$ is determined. Conclusions. Express-assessment of toxicity of waters of surface sources of water service and drinking water is expedient to conduct on $D$. magna using test-attribute FCB after 3-hour exposure. The high performance of the offered method is proved in conditions CF "Zhytomyrvodokanal». Use of test-attribute FCB in comparison to standard index (immobilization of $D$. magna) promoted increase of responsivity of biotesting for $28,33 \%$ and decrease of its duration for $73,11 \%$.

Key words: water biotesting, Daphnia magna S., immobilization, FCB, toxicity level.

Formulation of the problem. Pollution of natural and drinking water in our time is one of the global problems of society. Therefore, priority should be given to measures aimed at increasing the effectiveness of controls that are able to detect the main negative effects in a timely manner and to reproduce the real state of safety of the use of natural water and the consumption of drinking water by consumers [1-3]. In this control, it is advisable to strengthen the role of biological testing - a method that has several advantages over others: it is affordable and easy to implement, does not require complex equipment, is one of the most effective and fastest methods for determining the total action of toxic substances contained in water [4-5]. For test objects, creatures of almost all taxonomic groups from bacteria to mammals can be taken. However, in existing studies, preference is always given to unified organisms, which standard experiments are developed with. Among them, infusoria, daphnia, ceriodaphynia, guppies, common onions, salad, etc. are often used [5-8]. For a long time, these test objects were used to determine the toxicity of natural and sewage, and with the development of SSanRN (State sanitary rules and norms) 2.2.4-171-10 their use was "transferred" to drinking water [5]. However, for biotesting the quality of water from sources of water supply and drinking water, which is much cleaner than other waters, the traditional test characteristics of organisms (immobilization daphnia and ceriodaphnia) were not enough informative. In this regard, the search for test signs of unified creatures, through which high levels of pollution can be detected - from the lowest to the sublethal ones.

Analysis of recent research and publications. In literary sources during the last decade much attention has been paid to the feasibility of using highly sensitive organisms, through which it is possible more efficiently than in traditional ways to conduct an express assessment of the state of the aquatic environment. The reason for this is that standardized methods of biotesting have a number of disadvantages that do not allow with high informative value to assess the toxicity of water [3-5,7-9], especially low contaminated:

- insufficient sensitivity of organisms to low concentrations of pollutants in water and low levels of total water toxicity;

- application as the main test-sign of the index of immobilization of organisms (in fact, the death of creatures); 
- conducting research for a relatively long time in several stages.

Taking into account the mentioned features and the existing literature data on the significant increase in the effectiveness of biotesting through the use of more sensitive test-signs of organisms [5,9], we consider it necessary to apply such a function of test objects, which would be life-time, more sensitive to water pollution compared with the generally accepted, and allowed for a short period of time to determine the level of toxicity of water.

According to the Standard of the enterprise STP 17-08, approved on the Municipal Enterprise "ZhytomyrVodokanal" [8], as a test organism, D. magna was used, which is unified and designed to determine the immobilization of individuals within 24 and 48 hours [5-8]. Proceeding from this, it was suggested, without replacing the test object, to optimize the bioassay process and to create an original scale for the levels of water toxicity, which is consistent with SSanRN 2.2.4-171-10 [5].

The purpose of the research is to increase the information value of water biotesting from surface sources to supply and drinking water on crustaceans $D$. magna at the expense of using the test-sign of heart beat frequency (HBF).

Materials and methods. In order to realize the research objective, a comparative analysis of the basic (BS) and proposed (ZS) methods of biotesting of water toxicity, samples of which were selected in prepared dishes from the reservoirs of the Teteriv river, clean water reservoirs (CWR) and the water supply network at the Municipal Enterprise "Zhytomyrvodokanal" in April 2016. After sampling the water was poured into chemical cups $(100 \mathrm{ml})$ and formed control and experimental groups according to the following scheme:

- Control group - a test of a settled (24 hours) tap water;

- Test group D-1: water samples - from the Denyshivske reservoir;

- Test group D-2: water samples - from Vidsichne water intake;

- Test group D-3: water samples - from CWR 5000 m;

- Test group D-4: water samples - from CWR $20000 \mathrm{~m}$.

Test object: 24-hour youth daphnia (similar to age and size).

Test characteristics: immobilization (II) and heart beat frequency (HBF).

Exposition: BS - $48 \mathrm{~h}(\mathrm{n}=10)$ and AP - $3 \mathrm{~h}(\mathrm{n}=15)$.

Biotesting: BS - counting of active and immobilized individuals, AF - microscopy of individuals in vivo with the definition of HBF.

Experiments were carried out in triple repetition at water temperature $+20^{\prime} \mathrm{C} \pm 2 \mathrm{C}$ and other identical conditions. In the BS, the counting of daphnia specimens was carried out in tested water. In the Armed Forces, each individual pipette was taken from samples of tested water, placed on a slide in a drop of the same water, and after the definition of heart rate for 30 seconds and recalculation of these data for $1 \mathrm{~min}$, the average arithmetic was calculated. The obtained data were compared with the control. For each experimental water sample, the toxicity index (\%) for the SSanRN 2.2.4-171-10 [5] was calculated using the following formula:

$$
T=\frac{/ I_{k}-I_{0} /}{I_{k}} 100,
$$

where: $\mathrm{T}$ - index of toxicity, \%;

$\mathrm{I}_{\mathrm{t}}$ - the value of the test-reaction of individuals in the control;

$\mathrm{I}_{\mathrm{l}}$ - the value of the test-reaction of individuals in the experiment.

Since pollutants can cause both deceleration and acceleration of heart rate, it is advisable to determine the difference between the test and the reaction in the daphnia between the control and the test modulo.

Research results. A comparative analysis of the environmental effectiveness of methods of biotesting of water samples taken in reservoirs of the River Teteriv and reservoirs of clean water at the Municipal Enterprise "ZhytomyrVodokanal" is presented in the Table. 
The obtained data suggest that the proposed test for the rapid assessment of water on $D$. magna test heart rate is more sensitive to the determination of water toxicity than the immobilization of individuals. In addition, the use of heart rate can detect the presence of water pollution much faster than the traditional testsymptom MI. According to biotesting, a scale of levels of water toxicity is developed that is more convenient than in the standard [5] and is fully consistent with SSanRN 2.2.4-171-10. When it was created, it was taken into account that the toxicity index of water should not exceed $50 \%$ regardless of the test objects used in the research [5,7]: $1-25 \%$ - acceptable level of toxicity; $26-50 \%$ - low toxicity; $51-75 \%$ - average toxicity; $76-$ $100 \%$ - high toxicity.

Comparative analysis of methods of biotesting on D. magna water samples from the reservoirs of the Teteriv river and the CWR at the Municipal Enterprise "ZhytomyrVodokanal"

\begin{tabular}{|c|c|c|c|c|}
\hline \multirow[t]{2}{*}{ Test groups and figures } & \multicolumn{4}{|c|}{ Efficiency of biotesting according to test characteristics: } \\
\hline & $\begin{array}{c}\text { I" } \\
(T, \%)\end{array}$ & toxicity level & $\begin{array}{l}\text { HBF } \\
(T, \%)\end{array}$ & toxicity level \\
\hline \multicolumn{5}{|l|}{ D-1 (Denishivske Reservoir) } \\
\hline & absent & ATL & 35,4 & LTL \\
\hline \multicolumn{5}{|l|}{$\mathrm{D}-2$} \\
\hline (Vidsichne water intake) & absent & ATL & 27,6 & LTL \\
\hline D-3 & absent & & & \\
\hline (CWR 5 000) & & ATL & 24,1 & ATL \\
\hline $\mathrm{D}-4$ & absent & & & \\
\hline (CWR 20 000) & & ATL & 26,2 & LTL \\
\hline Exposure Duration & & & & - \\
\hline hours & 48 & - & 3 & \\
\hline Preparation for tests and & & - & & - \\
\hline $\begin{array}{l}\text { determination of test } \\
\text { characteristics, } \mathrm{h}\end{array}$ & 0,5 & & 0,75 & \\
\hline Number of research objects (n) & & - & & - \\
\hline & 10 & & 15 & \\
\hline
\end{tabular}

Note: II - immobilization of individuals;

HBF - heart beat frequency of individuals;

$\mathrm{T}$ - index of water toxicity (in relation to control);

levels of toxicity of water: ATL - admissible, LTL - low.

The proposed distribution of water toxicity levels will separate the actual absence of toxicity (1-25\%) from its low level, as well as highlight the most dangerous toxicity that can be so high that unlike the average level, causing loss of individuals $(76-100 \%)$.

In the conducted research on the test sign of immobilization daphnia, and in fact, in the absence of immovable specimens in all types of tested water, the lowest level of toxicity was detected. However, it is quite clear that water from surface water sources and drinking water can not have the exact same toxic effect. Therefore, it was decided to use such a test sign Daphnia, which would allow for a more detailed distribution of water by the index of toxicity. Comparison of the sensitivity of the immobilization index with the sensitivity of the physiological parameters of 24-hour individuals (color change, respiratory failure, peculiarities of motor activity, heart rate) to relatively small amounts of pollutants contained in drinking water and drinking water prepared at the Municipal Enterprise "ZhytomyrVodokanal" allowed to stay on the testsign of HBF, the definition of which is more effective compared with other physiological criteria. The rate of immobilization of individuals, which is considered standard in modern biotesting of water quality, even despite the ease of implementation (by counting the number of active and immovable daphnia), loses heart rate in a number of positions. In particular, the use of immobilization is associated with a relatively long exposure period (48 hours) and clarification of the condition of the animals in several stages (every 6 hours). 
It is these peculiarities of the method that complicate the process of operative obtaining of biotesting results. When using heart rate this problem is partially eliminated because the exposure time is only 3 hours. And although the technique of determining heart rate in Daphne is somewhat more complex compared with observations on the immobilization of individuals and requires more time spent directly on testing each daphnia ( $0.5 \mathrm{~min}$ / person), it is fully offset by a significantly lower overall duration of research and a higher probability of the results, allowing increase the number of individuals in the control and experimental groups.

In the literature there is evidence that the test-symptom of the HBF daphnia is successfully used to detect pesticide pollution in water [10]. However, according to our data, this physiological parameter may well be used to determine the overall toxicity of water. The process of respiration in the lower crustaceans, as well as in other animal forms, is closely related to the functioning of their cardiovascular system, in particular, with the reduction of the heart. Therefore, significant impacts on the respiratory system will lead to a change in the HBF. However, among the pollutants there are those that can both exacerbate and weaken the work of the HBF. Over time, the response to pollutants may also change. In any case, in the presence and absence of harmful substances in water, the cardiac activity of daphnia should be different. If this difference exceeds $50 \%$, the level of water pollution should be considered significant.

Since practically all toxicants refer to biologically active substances, their presence in water is accompanied by the process of oxidation, and, consequently, in the contaminated water, the content of dissolved oxygen gradually decreases. This in turn causes an increase in the physiological mechanism of compensating the deficit of oxygen in the lower crustaceans and contributes to an increase in their heart rate [11]. Therefore, the respiratory and cardiovascular systems of daphnia under similar conditions can be considered one of the most sensitive constituents of the body, one of the first, in a rather short time, will react to polluted water. To perform an express evaluation, this test sign, even considering the need to count the number of heart counts under a microscope, is more informative than the generally accepted indicator. It will be especially important to have a HBF if it is necessary to quickly determine the state of the water environment in the event of volley contaminations and the deterioration of the quality of drinking water due to the formation of it in the process of preparation (for example, due to chlorination) under conditions of water channels of dangerous compounds.

By way of biotesting according to the test-symptom of the HBF daphnia in the waters of the reservoirs of the Teteriv river and the CWR 20000 Municipal Enterprise "ZhytomyrVodokanal" was found to have a low level of toxicity. And only in CWR 5000 the water toxicity did not exceed the permissible level, ie the value of the toxicity index $(24.1 \%)$ only approached $25 \%$. Generally, the indexes of toxicity of experimental waters in the HBF of individuals were actually $24.1-35.4 \%$ higher compared with the indices obtained during biotesting for the immobilization of individuals. This means that the heart rate test significantly improved the sensitivity of biotesting in daphnia, even when the $50 \%$ limit on water hazard was not exceeded. The proposed method turned out to be about the determination of water toxicity by an average of $28,33 \%$ more informative, and over time - by $73,11 \%$ less than the base version. In addition, an increase in the number of daphnia in each group from 10 to 15 will allow to some extent increase the probability of biotesting of water (in three replicates - 45 individuals per group).

Although the determination of the HBF test-reaction proposed for conducting an express-assessment of the potential hazard of water from surface water sources and drinking water is more complicated by the implementation technique than the usual observation of the immobilization of individuals, it is fully offset by increased information value, much shorter research duration, and higher probability of the results obtained.

Thus, the proposed method of biotesting at heart rate daphnia in comparison with the standard is more sensitive, fast and accurate in the definition, allows to adequately assess the impacts of anthropogenic factors on water of different quality, if they have not only high, but also low levels of pollution.

\section{Conclusions}

Express-estimation of the potential water hazard of surface water sources and drinking water is advisable to do with the proposed method of bioassay for the test-reaction of HBF daphnia. In the conditions of the Municipal Enterprise "ZhytomyrVodokanal", this method compared with the generally accepted average was 
$28.33 \%$ more informative, $73.11 \%$ less protracted and allowed to increase the probability of the received data due to high sensitivity to low levels of water pollution and an increase in the number of test-objects.

\section{References}

1. River watch. Manual for public environmental monitoring. (2015). SPb.: Friends of the Baltics. Coalition Clean Baltics, 32 p. (in English).

2. El-Nahhal I.M., Zourab S. M., Kodeh F. S. (2013). Nanostructured zinc oxide-cotton fibers: synthesis, characterization and applications. Jornal of Materials Science: Materials in Electronics, pp. 3970-3975(in English).

3. Malik A., Grohmann E., Akhtar R. (2014). Environmental Deterioration and Human Health: Natural and anthropogenic determinants. Dordrecht Heidelberg, London, New York: Springer, pp. 10-400. (in English).

4. Söderbaum P., Tortajada C. (2011). Perspectives for water management within the context of sustainable development. Water International. Vol. 36, no. 7, November 2011, pp. 812-827. (in English).

5. DSanPiN 2.2.4-171-10 «Higiyenichni vymogy do vody pytnoi, prysnachenoi dlya spo vzhyvannya ludynoiu» [State Sanitary rules and norms 2.2.4-171-10 "Hygiene requirements to drinking water intended for human consumption"], no.452/17747. Kyiv: Ministerstvo okhorony sdorovia Ukrainy [Ministry of Healthcare of Ukrain]. Derzhavni standartni normy ta pravyla [chynnyi vid 1.07.2010]. — 50 p. (in Ukrainian).

6. Nevalainen L., Ketola M., Korosi J.B. et al. (2014). Zooplankton (Cladocera) species turnover and longterm decline of Daphnia in two high mountain lakes in the Austrian Alps, Hydrobiologia. Vol. 722 (1). pp. 7591. (in English).

7. BS 6068-5. 28: 2000, ISO 10706: 2000. Water quality. Determination of long term toxicity of substances to Daphnia magna Straus (Cladocera, Crustacea), 26 p. (in English).

8. STP 17-08 Metodyka [Method]. Tsitofisiologichna ekspres-otsinka toksichnosti vody (Biotestuvannia) [Cytophysiological express-evaluation of water toxicity (Biotesting)]. Komunalne pidpryiemstvo «Zhytomyrvodokanal» [Munitipal Enterprise «Zhytomyr Waterworks»], Zhytomyr [diisnyi vid 10.09.2008], 15

p. (in Ukrainian).

9. Lampert W., Sommer U. (2007). Limnoecology. Oxford University Press: Oxford, New York, 324 p. (in English).

10. Kulagina K.V. (2011). Issledovaniye savisimosti chactoty cerdechnykh cokrashcheniy Daphnia magna ot koncentratsyi pestitsydov [Research into the relationship between the heart rates of Daphnia magna from concentration of pesticides]. Fundamentalnye issledovania [Fundamental research], no. 3, pp. 191-197. (in Russian).

11. Jakob U., Reichmann D. (2013). Oxidative Stress and Redox Regulation, Dordrecht, Heidelberg, London, New York: Springer, pp. 59-426. (in English). 